\title{
IMPACT OF SOME OVERSEAS MONETARY VARIABLES ON INDONESIA: SVAR APPROACH
}

\author{
Ahmad Subagyo \\ STIE GICI BUSINESS SCHOOL, INDONESIA \\ Armanto Witjaksono \\ BINA NUSANTARA UNIVERSITY, INDONESIA
}

date of paper receipt:

21.11.2017.

Review paper date of sending to review:

23.11.2017. date of review receipt:

29.11.2017.

\section{SUMMARY}

This study aims to investigate how the influence of monetary variables from abroad to Indonesia's monetary conditions. This study uses exchange rate variables, interest rates of U.S. central banks, world oil prices and interest rates of Indonesian banks. This study proposes a short-term SVAR analysis using FEVD and IRF as an additional analysis tool. From the research done in the explanation that with SVAR model that in the proposal is less precise, the result for IRF and FEVD analysis can not be made as additional material of analysis tool from SVAR model which in proposal.

Keywords: Monetary variable; FFF; WP; BI Rate.

JEL classification: E52; F31.

\section{INTRODUCTION}

Some of the studies that emirically focus on the impact of U.S. monetary policy have established delayed overshooting and only wait for the peak of response that will occur 1 to 3 years, before it happens right away. Thus in Dornbusch (1976) it has been explained that the evidence of monetary accumulation that occurs, in turn creates a 'conditional futures puzzle', to gain profit by borrowing overseas or investing in the US.

In Frankel (1986), Clarida and Gali (1994), Evans (1994), Eichenbaum and Evans (1995), Kalyvitis and Michaelides (2001) and Lobo et al. (2006) describes in his study of the response of U.S. monetary variables, by looking at the behavior of the dollar currency, which can behave overshooting 'for almost 2 to 3 years against the major currencies of other countries. It is also assessed in other studies in Japan, some use weekly, monthly and yearly data, and find that the dollar currency is overshooting, up to a period of up to two or three years of delays against the yen. They argue that the dollar strengthened against the yen exchange rate over the period of the first five months, which is marked by a monetary shock in advance. And in other studies, explaining empirically, that the U.S. monetary policy performing contractions such as domestic interest rates that have increased relative to foreign interest rates, as well as the dollar strengthened and specified with output value, so as to be able to know the position of business cycles Country of the United States and domestic countries relative. The occurrence of persistent deviations from a hypothesis relates to an undetectable interest rate parity characteristic of a country's economic structure, making its 
asymmetry in the application of monetary policy in a country. But a new finding was found in the study, about changes in the impact of the Federal Funds Rate (FFR) on daily currency values, as well as finding surprises related to monetary contraction.

\section{LITERATURE REVIEW}

In some studies and theories of economic literature explain how the impact of a monetary variable from abroad on the domestic monetary variable of a State, which can create an economic bubble in it. If viewed, in the literature, there are 3 explanations of the view of the monetary state of a State to the monetary conditions of a State that affect indirectly. This can be made as a view and an approach, in improving liquidity and liaison functions within a monetary analysis transmission. Hereinafter in the era of 1920, some economists from Austria. believes in an asset price increase, which is due to a slightly lower and more stable inflationary environment. The next view is explained in an equilibrium analysis. Where the monetary conditions can stabilize the price level in general and ultimately lead to fluctuations in asset prices. In monetary conditions can affect the economic state of a State in general, especially those associated with exchange rates there are 3 places:

1. Impact of monetary conditions on a currency if there is an expansionary monetary condition, there will be an increase in the money supply in the domestic country, with the occurrence of interest rate cuts, capital outflows will be able to reduce the supply of foreign currency, thus increasing the exchange rate. If, on the other hand, the central bank intervenes on the value of the currency, then the market will not allow the exchange rate of a currency to rise. Thus the reserves will enter the market. Making foreign currency purchases in the community, will cause the increase in the money supply to decrease, so as to neutralize the value and the amount of money in circulation.

2. Impact of monetary conditions on the price level If a central bank implements an expansive monetary condition, it will lead to an increase in the money supply, and may increase prices in general. The occurrence of fluctuations in domestic prices to rise, making the price of goods and services domestic demand is relatively more expensive, compared to foreign goods, so that the competitiveness of exports globally to decline. On the other hand, supply of a currency will decline. This led to a two-place exchange rate increase.

3. Impact of monetary conditions on the portfolio If in a State, the Central Bank conducts an expansive monetary state, it may lead to an increase in the money supply, and indirectly decrease the interest rate. With reduced interest rates, bank deposits make it less attractive, and most customers will withdraw their money from the bank, then invest it in other instruments, not to mention money markets.

\section{METHODOLOGY, TIME AND DATA RESEARCH}

\section{RESEARCH METHOD}

In this study used SVAR model, which assumes block exocception for small domestic open economic variables (Indonesia) relative to external variables (U.S.A). In Kim and Roubini (2000) explains that a non-recursive VAR model that allows monetary conditions to respond simultaneously, in the case of shocks to exchange rate variables, and will be able to complete part of the pending overshooting effect'. They also provide evidence of an unexpected rise in the U.S. monetary conditions, making interest rates in the short-term, non-US G7 countries increase, so the currency in the country is depreciating. This is further clarified by Faust and Rogers (2003) that the recursive SVAR model can be a powerful model for seeing how assumptions change over identification, and will result in "sensitive overshooting", against the assumptions adopted. 


\section{TIME OF RESEARCH}

This research was conducted in October 2017.

\section{SOURCE OF DATA RESEARCH}

Data in research can be from various sources such as website, Bank Indonesia, world bank, IMF, Blomberg and others. The data in this study consist of 1 monetary variable from USA and 1 variable of world oil price, assumed to have influence to 2 monetary Indonesia that is BI rate and exchange rate Rp / USD during period of december 1984 - December 2015

\section{RESULT AND DISCUSSION}

From the model proposed in this study, using short-term SVAR analysis, the assumption of 2 influencing variables and 2 variables that are influenced. The scale of the model in use, is a small scale model, assuming for a small open Indonesia economy. In table 1 below we see the results for the proposed research model.

Table 1 Result for SVAR Model short run analisys

\begin{tabular}{|c|c|c|c|c|}
\hline \multicolumn{5}{|c|}{ Structural VAR Estimates } \\
\hline \multicolumn{5}{|c|}{ Model: $\mathrm{Ae}=\mathrm{Bu}$ where $\mathrm{E}\left[\mathrm{uu}^{\prime}\right]=\mathrm{I}$} \\
\hline \multicolumn{5}{|c|}{ Restriction Type: short-run text form } \\
\hline & Coefficient & Std. Error & z-Statistic & Prob. \\
\hline $\mathrm{C}(2)$ & -0.081244 & 0.071208 & -1.140941 & 0.2539 \\
\hline $\mathrm{C}(4)$ & 30.68367 & 84.65927 & 0.362437 & 0.7170 \\
\hline $\mathrm{C}(5)$ & 21.05788 & 212.5011 & 0.099095 & 0.9211 \\
\hline $\mathrm{C}(7)$ & -0.663528 & 0.371917 & -1.784074 & 0.0744 \\
\hline $\mathrm{C}(8)$ & 0.547891 & 0.931655 & 0.588084 & 0.5565 \\
\hline $\mathrm{C}(9)$ & 0.000991 & 0.000800 & 1.238033 & 0.2157 \\
\hline $\mathrm{C}(1)$ & 3.037527 & 0.392143 & 7.745967 & 0.0000 \\
\hline $\mathrm{C}(3)$ & 1.184704 & 0.152945 & 7.745967 & 0.0000 \\
\hline $\mathrm{C}(6)$ & 1378.896 & 178.0147 & 7.745967 & 0.0000 \\
\hline $\mathrm{C}(10)$ & 6.044421 & 0.780331 & 7.745967 & 0.0000 \\
\hline Log likelihood & -479.5340 & & & \\
\hline \multicolumn{5}{|l|}{ Estimated A matrix: } \\
\hline 1.000000 & 0.000000 & 0.000000 & 0.000000 & \\
\hline 0.081244 & 1.000000 & 0.000000 & 0.000000 & \\
\hline-30.68367 & -21.05788 & 1.000000 & 0.000000 & \\
\hline 0.663528 & -0.547891 & -0.000991 & 1.000000 & \\
\hline \multicolumn{5}{|c|}{ Estimated B matrix: } \\
\hline 3.037527 & 0.000000 & 0.000000 & 0.000000 & \\
\hline 0.000000 & 1.184704 & 0.000000 & 0.000000 & \\
\hline 0.000000 & 0.000000 & 1378.896 & 0.000000 & \\
\hline 0.000000 & 0.000000 & 0.000000 & 6.044421 & \\
\hline
\end{tabular}

Source : Proceed by author 
From the results of table 1 that has been in the show, how, the probability value for the matrix model C (i) as visible. The matrix estimation number A and the matrix estimation number B are significant, thus the results can not be determined, because the $\mathrm{p}$ value does not appear from the model in the proposal. So we can make sure the model in the proposal is not correct. The IRF FEVD analysis is used to view the continuation of the analysis model for short or long term analysis within the proposed SVAR model, as presented in Table 2 and figure 1 below:

Table 2 Result for FEVD on SVAR Model short run analisys

\begin{tabular}{|c|c|c|c|c|}
\hline \multicolumn{5}{|c|}{$\begin{array}{l}\text { Response of } \\
\text { BI_RATE: }\end{array}$} \\
\hline Period & BI_RATE & FFF_USA_ & US_\$_RP & WP \\
\hline 1 & 3.037527 & 0.000000 & 0.000000 & 0.000000 \\
\hline 2 & 1.147713 & 0.583851 & 0.558856 & -0.820031 \\
\hline 3 & 1.321999 & 0.055468 & -0.100217 & -0.652667 \\
\hline 4 & 0.789536 & -0.287872 & -0.236679 & -0.712479 \\
\hline 5 & 0.659244 & -0.349011 & -0.452346 & -0.563114 \\
\hline 6 & 0.429393 & -0.123097 & -0.289504 & -0.493035 \\
\hline 7 & 0.328922 & 0.125001 & -0.210823 & -0.433746 \\
\hline 8 & 0.246110 & 0.222632 & -0.188880 & -0.403594 \\
\hline 9 & 0.213805 & 0.169486 & -0.296365 & -0.366556 \\
\hline 10 & 0.192420 & 0.070815 & -0.414743 & -0.322693 \\
\hline \multicolumn{5}{|c|}{$\begin{array}{l}\text { Response of } \\
\text { FFF_USA_: }\end{array}$} \\
\hline Period & BI_RATE & FFF_USA_ & US_\$_RP & WP \\
\hline 1 & -0.246781 & 1.184704 & 0.000000 & 0.000000 \\
\hline 2 & -0.054947 & 0.926044 & 0.179646 & -0.108706 \\
\hline 3 & 0.066088 & 0.253405 & -0.515271 & -0.174418 \\
\hline 4 & 0.133821 & -0.294994 & -0.845480 & -0.115982 \\
\hline 5 & 0.164611 & -0.329602 & -0.902370 & -0.069423 \\
\hline 6 & 0.169420 & -0.047041 & -0.692689 & -0.066195 \\
\hline 7 & 0.183202 & 0.225927 & -0.520451 & -0.110839 \\
\hline 8 & 0.205969 & 0.292707 & -0.497324 & -0.165078 \\
\hline 9 & 0.233210 & 0.189523 & -0.602323 & -0.199787 \\
\hline 10 & 0.253874 & 0.061770 & -0.721987 & -0.210272 \\
\hline \multicolumn{5}{|c|}{$\begin{array}{l}\text { Response of } \\
\text { US_\$_RP: }\end{array}$} \\
\hline Period & BI_RATE & FFF_USA_ & US_\$_RP & WP \\
\hline 1 & 88.00576 & 24.94736 & 1378.896 & 0.000000 \\
\hline 2 & -47.17810 & 190.0724 & 866.7500 & -80.53614 \\
\hline 3 & -137.9651 & -55.19640 & 950.3978 & -3.631262 \\
\hline 4 & -182.6440 & -212.0156 & 735.9143 & 48.93634 \\
\hline 5 & -243.4690 & -254.8827 & 769.3456 & 124.6090 \\
\hline 6 & -281.8265 & -176.8618 & 828.9266 & 175.4896 \\
\hline 7 & -315.9179 & -93.12523 & 923.7851 & 207.9300 \\
\hline 8 & -335.2796 & -67.40779 & 967.2353 & 229.6962 \\
\hline
\end{tabular}




\begin{tabular}{|l|c|c|c|r|}
\hline 9 & -350.3550 & -100.8037 & 978.1032 & 251.9631 \\
\hline 10 & -363.2238 & -149.6658 & 980.4891 & 278.1253 \\
\hline Response of WP: & & & & \\
\hline Period & BI_RATE & FFF_USA_ & US_\$_RP & WP \\
\hline 1 & -2.063495 & 0.673807 & 1.366237 & 6.044421 \\
\hline 2 & -1.486515 & -0.149950 & 3.444947 & 3.779275 \\
\hline 3 & -0.949927 & -0.861065 & 2.269842 & 3.244021 \\
\hline 4 & -1.045965 & -1.400534 & 3.011124 & 2.760058 \\
\hline 5 & -0.999479 & -1.255372 & 3.265180 & 2.436569 \\
\hline 6 & -1.163432 & -0.890171 & 4.040422 & 2.162894 \\
\hline 7 & -1.266521 & -0.623439 & 4.495251 & 1.945455 \\
\hline 8 & -1.405560 & -0.627320 & 4.815038 & 1.799379 \\
\hline 9 & -1.527274 & -0.789085 & 4.963237 & 1.738820 \\
\hline 10 & -1.663688 & -0.938528 & 5.136699 & 1.743431 \\
\hline $\begin{array}{l}\text { Cholesky Or- } \\
\text { dering: BI_RATE }\end{array}$ & & & & \\
$\begin{array}{l}\text { FFF_USA_ } \\
\text { US_\$_RP WP }\end{array}$ & & & & \\
\hline
\end{tabular}

Source : Proceed by author

Figure 1 Result for IRF on SVAR Model short run analisys
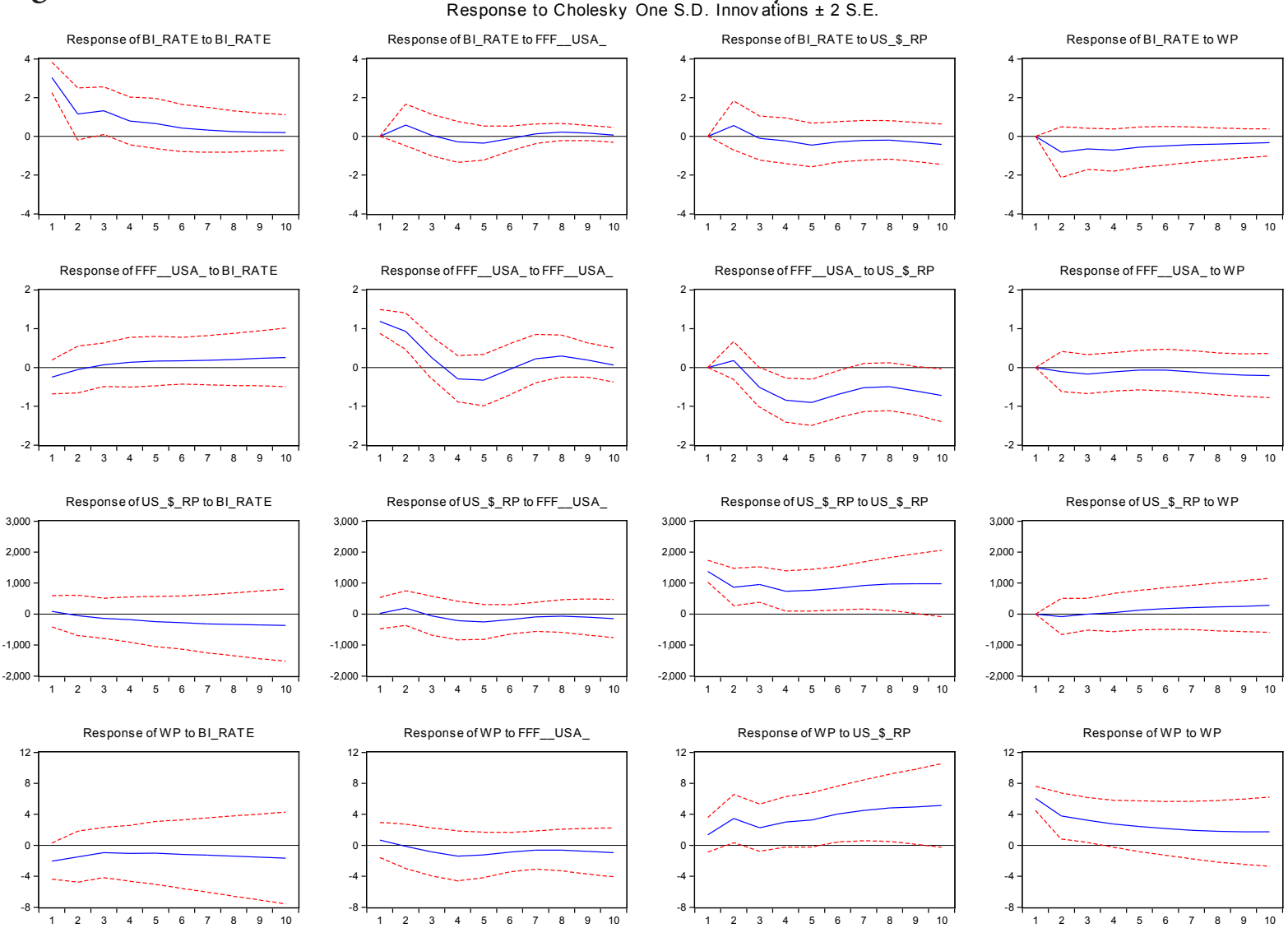

Source : Proceed by author

The FEVD and IRF results in Table 2 and Figure 1 show that the relationship between BI_Rate, FFF, exchange rate and world oil prices is explained from period 1 to period 10 , as illustrated by the response rate generated. Likewise for the movement of impulse response from the first period up to the tenth period that looks far away for the overall variables in the perusal. 


\section{CONCLUSION}

From the research that has been done, the conclusion that the proposed model is less precise, so that SVAR produced less able to provide adequate opinions. However, from FEVD and IRF in the show can explain how the variables in carefully away from the balance point, for each variable for the period of the first to the tenth period. In response, the response to varabel from abroad affecting the state of Indonesia's monetary condition is explained from FEVD and IRF. According to the author of this analysis can be used if the model SVAR in the proposal has met the right form.

\section{REFERENCE}

1. Christiano L., M. Eichenbaum, and C. Evans, 1999, 'Monetary policy shocks: What have we learned and to what end?', in J. Taylor and M. Woodford (eds.), Handbook of Macroeconomics, Volume 1A, Elsevier Science: Amsterdam.

2. Clarida R., 2001, 'The empirics of monetary policy rules in open economies', International Journal of Finance and Economics, 6, 315-323.

3. Clarida R. and J. Gali, 1994, 'Sources of real exchange rate fluctuations: How important are nominal shocks?', Carnegie-Rochester Conferences Series on Public Policy, 41, 1-56.

4. Clarida R., J. Gali and M. Gertler, 1998, 'Monetary policy rules in practice: Some international evidence', European Economic Review, 42, 6, 1033-67.

5. Cushman D.O. and T. Zha, 1997, 'Identifying monetary policy in a small open economy under flexible exchange rates', Journal of Monetary Economics, 39, 3, 433-48.

6. Cooper R.N. and J.S. Little, 2001, 'U.S. monetary policy in an integrating world: 1960 to 2000', New England Economic Review, 3, 33-56.

7. Dornbusch R., 1976, 'Expectations and exchange rate dynamics', Journal of Political Economy, $84,6,1161-76$.

8. Eichenbaum M. and C. Evans, 1995, 'Some empirical evidence on the effects of shocks to monetary policy on exchange rates', Quarterly Journal of Economics, 110, 4, 975- 1009.

9. Evans C., 1994, 'Interest rate shocks and the dollar', Economic Perspectives, Federal Reserve Bank of Chicago, 18, 11-24.

10. Faust J. and J.H. Rogers, 2003, 'Monetary policy's role in exchange rate behavior', Journal of Monetary Economics, 50, 1403-24.

11. Frankel J.A., 1986, 'The implications of mean-variance optimization for four questions in international macroeconomics', Journal of International Money and Finance, 5, S53- 75.

12. Frenkel M., C. Pierdzioch, and G. Stadtmann, 2005, 'Japanese and US interventions in the Yen/ US dollar market: Estimating the monetary authorities' reaction functions', Quarterly Review of Economics and Finance, 45, 680-98.

13. Froot K. and R. Thaler, 1990, Anomalies: Foreign exchange', Journal of Economic Perspectives, 4, 179-92.

14. Gordon D. and E. Leeper, 1994, 'The dynamic impacts of monetary policy: An exercise in tentative identification', Journal of Political Economy, 102, 228-47.

15. Hodrick R., 1987, The Empirical Evidence on the Efficiency of Forward and Futures Foreign Exchange Markets, Harwood Academic Publishers: London.

16. Jang K. and M. Ogaki, 2004, 'The effects of monetary policy shocks on exchange rates: A structural vector error correction approach, Journal of the Japanese and International Economics, 18, 99114.

17. Kim S. and N. Roubini, 2000, 'Exchange rate anomalies in the industrial countries: A solution with the structural VAR approach', Journal of Monetary Economics, 45, 561-86.

18. Lewis K., 1995, Are foreign exchange intervention and monetary policy related, and does it really 
matter?', Journal of Business, 68, 185-214.

19. Lobo, B.J., A. Darrat and S. Ramchander, 2006, 'The asymmetric impact of monetary policy on currency markets', The Financial Review, 41, 289-303.

20. Obstfeld M. and K. Rogoff, 1996, Foundations of International Macroeconomics, MIT Press: Cambridge.

21. Rudebusch G., 1998, 'Do measures of monetary policy in a VAR make sense?', International Economic Review, 39, 907-31.

22. Sarno L. and M.P. Taylor, 2001, 'Official intervention in the foreign exchange market: Is it effective and, if so, how does it work?', Journal of Economic Literature, 39, 839- 68.

23. Sims C. and T. Zha, 1999, 'Error bands for impulse responses', Econometrica, 67, 5, 1113-55.

24. Weber A., 1996, 'Foreign exchange intervention and international policy coordination: Comparing the G3 and EMS experience, in: M.B. Canzoneri, W.J. Ethier and V. Grilli (eds.), The New Transatlantic Economy, Cambridge University Press: Cambridge. 